\title{
Intrapair Differences of the Blood Cell Components and Lymphocyte Subsets in Monozygotic and Dizygotic Twins
}

\author{
Y. Yokoyama', T. Akiyama² \\ 'Department of Public Health, Kinki University School of Medicine, 377, Ohnohigashi \\ Osakasayama city, Osaka, 589, Japan; ${ }^{2}$ Central Clinical Laboratory, Kinki University \\ Hospital, 377, Ohnohigashi Osakasayama city, Osaka, 589, Japan
}

\begin{abstract}
We evaluated the relative influence of genetic and environmental factors on leukocytes, lymphocytes, neutrophils, monocytes, erythrocytes, reticulocytes, hemoglobin, platelets, T lymphocyte subsets, and NK marker cells in monozygotic (MZ) and dizygotic (DZ) twins. Peripheral blood components were measured in 154 healthy twin pairs (118 MZ pairs and $36 \mathrm{DZ}$ pairs) and lymphocyte subsets in 48 healthy twin pairs (38 MZ pairs and $10 \mathrm{DZ}$ pairs).

Platelets and erythrocytes showed higher intraclass correlations in the MZ pairs than in the DZ pairs in the males. However, in the females, the intraclass correlations for these components were similar between the $\mathrm{MZ}$ and $\mathrm{DZ}$ pairs. Neutrophils and monocytes showed low intraclass correlations in the $\mathrm{MZ}$ pairs. The absolute number of $\mathrm{CD}^{+}$ cells and the $\mathrm{CD}^{+} / \mathrm{CD}^{+}$cell ratio showed high intraclass correlations regardless of age in the $\mathrm{MZ}$ pairs in both males and females. The intraclass correlation for the absolute number of $\mathrm{CD}^{+}$cells was low in pairs aged $\geq 60$ years in the $\mathrm{MZ}$ pairs. The absolute numbers of $\mathrm{CD} 16^{+}$cells and $\mathrm{CD}^{+} 6^{+}$cells showed high intraclass correlations regardless of age in the $M Z$ pairs.
\end{abstract}

Key words: Twins, Platelet, Erythrocyte, T lymphocyte subset, NK cell, Age

\section{INTRODUCTION}

Studies on twins are imporant to analyze human responses involving both genetic and environmental factors. Since monozygotic (MZ) twins have the same genes but live in different environments, they provide useful data on the influence of environmental factors to epidemiologists.

In recent years, remarkable progress has been made in immunological studies. These immunological studies often use twins. Some studies have analyzed the serum concen- 
trations of immunoglobulins in twins $[5,6,8]$. There are only a few studies in twins that analyzed lymphocyte subsets or other blood cell components from the genetic aspect. One of them reported marked intrapair differences in the CD8 T cell compartment between $\mathrm{MZ}$ twins but strict regulation of CD4 T cells expressing the Vß gene [4].

In this study, we evaluated the influence of genetic and environmental factors on leukocytes, lymphocytes, neutrophils, monocytes, erythrocytes, reticulocytes, hemoglobin, platelets, T lymphocyte subsets, and NK marker cells in MZ and dizygotic (DZ) twin pairs. The influence of environmental factors including age and lifestyle were analyzed in MZ twins, as well.

\section{MATERIALS AND METHODS}

\section{Subjects}

MZ and DZ twins were recruited from 2000 pairs in the Kinki University Adult Twin Registry $[9,10,17,18,19]$. The twin pairs in this registry were collected by midwife records, posters, publicity activities, and follow up of the subjects in the previous twin studies with cooperation of retired researchers. Among the twin pairs, 210 pairs volunteered to undergo comprehensive medical examination. Of the 210 pairs, 154 without history of allergic symptoms, diabetes mellitus, or rheumatism or abnormalities by routine blood examination, blood biochemical examination, or urinalysis were included in this study. $\mathrm{CD}^{+}, \mathrm{CD}^{+}$, and $\mathrm{CD} 8^{+}$cells were measured in 48 pairs (38 $\mathrm{MZ}$ pairs and 10 $\mathrm{DZ}$ pairs). $\mathrm{CD} 16^{+}$and $\mathrm{CD}^{+} 6^{+}$cells were also measured in 32 (23 MZ and $9 \mathrm{DZ}$ pairs) of the 48 pairs.

Twin zygosity was determined on the basis of the results of phenylthiocarbamide (PTC) taste blindness test and 9 blood type systems: ABO, Rh (C, c, D, E, e), MN (M, $\mathrm{N})$, Lewis $\left(\mathrm{Le}^{\mathrm{a}}, \mathrm{Le}^{\mathrm{b}}\right), \mathrm{P}\left(\mathrm{P}_{1}\right)$, Duffy $\left(\mathrm{Fy}^{\mathrm{a}}, \mathrm{Fy}^{\mathrm{a}}\right)$, Kidd $\left(\mathrm{Jk}^{\mathrm{a}}, \mathrm{Jk}^{\mathrm{b}}\right)$, Kell $(\mathrm{k})$, and Diego $\left(\mathrm{Di}^{\mathrm{a}}\right)$. There were $118 \mathrm{MZ}$ pairs (67 male and 51 female pairs), and $36 \mathrm{DZ}$ twins (24 male and 12 female pairs). The mean age \pm standard deviation was $54.9 \pm 11.9$ years (range, 20-81 years) in all male $M Z$ pairs, $49.4 \pm 13.0$ years (17-74 years) in all female $M Z$ pairs, $57.7 \pm 13.2$ years (21-90 years) in all male DZ pairs, and $46.1 \pm 12.2$ years (31-73 years) in all female $\mathrm{DZ}$ pairs. In the pairs who underwent measurement of $\mathrm{CD}^{+}, \mathrm{CD}^{+}$, and $\mathrm{CD}^{+}$cells, the mean age was $53.9 \pm 13.2$ years $(28-69$ years) in the male $\mathrm{MZ}$ pairs, $51.3 \pm 10.5$ years (34-74 years) in the female MZ pairs, and $53.1 \pm 15.9$ years $(31-74$ years) in the male and female DZ pairs. In the pairs who underwent measurement of $\mathrm{CD}^{\circ} 6^{+}$and $\mathrm{CD}^{+} 6^{+}$cells, the mean age was $53.1 \pm 15.1$ years $(28-69$ years) in the male $\mathrm{MZ}$ pairs, $43.3 \pm 6.3$ years (34-52 years) in the female $\mathrm{MZ}$ pairs, and $52.8 \pm 16.8$ years (31-74 years) in the male and female DZ pairs.

\section{Methods}

The subjects were told not to have breakfast on the day of examination. Blood samples $(20 \mathrm{ml})$ were obtained via the brachial median vein. Blood cells were counted, and the 
percentage of lymphocytes, neutrophils, and monocytes were determined by MayGiemsa staining. Reticulocytes were counted by the Brecher's method. Hemoglobin was measured by the oxyhemoglobin method.

Lymphocyte subsets were measured by flow cytometry [7, 12, 13, 14] using FITClabeled monoclonal antibodies CD3 (OKT3), CD8 (OKT8), CD16 (OKNK) (Orth Pharmaceuticals), CD4 (Leu3a), and CD56 (Leul9) (Becton Dickinson). These antibodies react with mature $\mathrm{T}$ cells, cytotoxic/suppressor $\mathrm{T}$ cells, FcIgG receptors of NK cells, helper/inducer $\mathrm{T}$ cells, and NK cells and cytotoxic $\mathrm{T}$ cells, respectively. The absolute numbers of $\mathrm{CD}^{+}, \mathrm{CD}^{+}, \mathrm{CD} 8^{+}, \mathrm{CD} 16^{+}$and $\mathrm{CD}^{+} 6^{+}$cells were calculated as percentages of lymphocytes. The absolute numbers of these cells were used for analysis of lymphocyte subsets in this study on twins.

\section{Data analysis}

Intraclass variation, interclass variation, the variation ratio (interclass/intraclass variation), and the coefficient of intraclass variation were analyzed. The skewness and kurtosis of data distribution were tested by Fisher's cumulant method [3]. In variables not showing normal distribution of raw data, data were $\log _{10}$ transformed. For analysis of variance, Snedecor's formula [16] was used. Eosinophils and basophils were excluded from analysis because the number of cells was small.

\section{RESULTS}

\section{Intraclass Correlation Coefficient}

Table 1 shows the mean values and the intraclass correlation for leukocytes, lymphocytes, neutrophils, monocytes, erythrocytes, reticulocytes, hemoglobin, and platelets. In the male MZ, erythrocytes showed the highest intraclass correlation (0.806) among the 8 variables. The intraclass correlations for erythrocytes and platelets were significantly higher in the male MZ pairs than in the male DZ pairs. In the female MZ pairs, hemoglobin showed the highest intraclass correlation $(0.673)$.

Table 2 shows the mean absolute numbers and the intraclass correlations of $\mathrm{CD}^{+}$, $\mathrm{CD}^{+}, \mathrm{CD}^{+}, \mathrm{CD} 16^{+}, \mathrm{CD} 56^{+}$cells. The intraclass correlations for all variables were higher in the $\mathrm{MZ}$ pairs than in the $\mathrm{DZ}$ pairs. The absolute number of $\mathrm{CD} 56^{+}$cells differed between the males and females (male, 0.820; female, 0.574).

\section{Influence of Age}

Table 3 shows the mean values and intraclass correlations for leukocytes, lymphocytes, neutrophils, monocytes, erythrocytes, reticulocytes, hemoglobin, and platelets according to age. The intraclass correlation for reticulocytes was significantly higher in the pairs aged $<40$ years than in those aged $40-59$ years or $\geq 60$ years. 


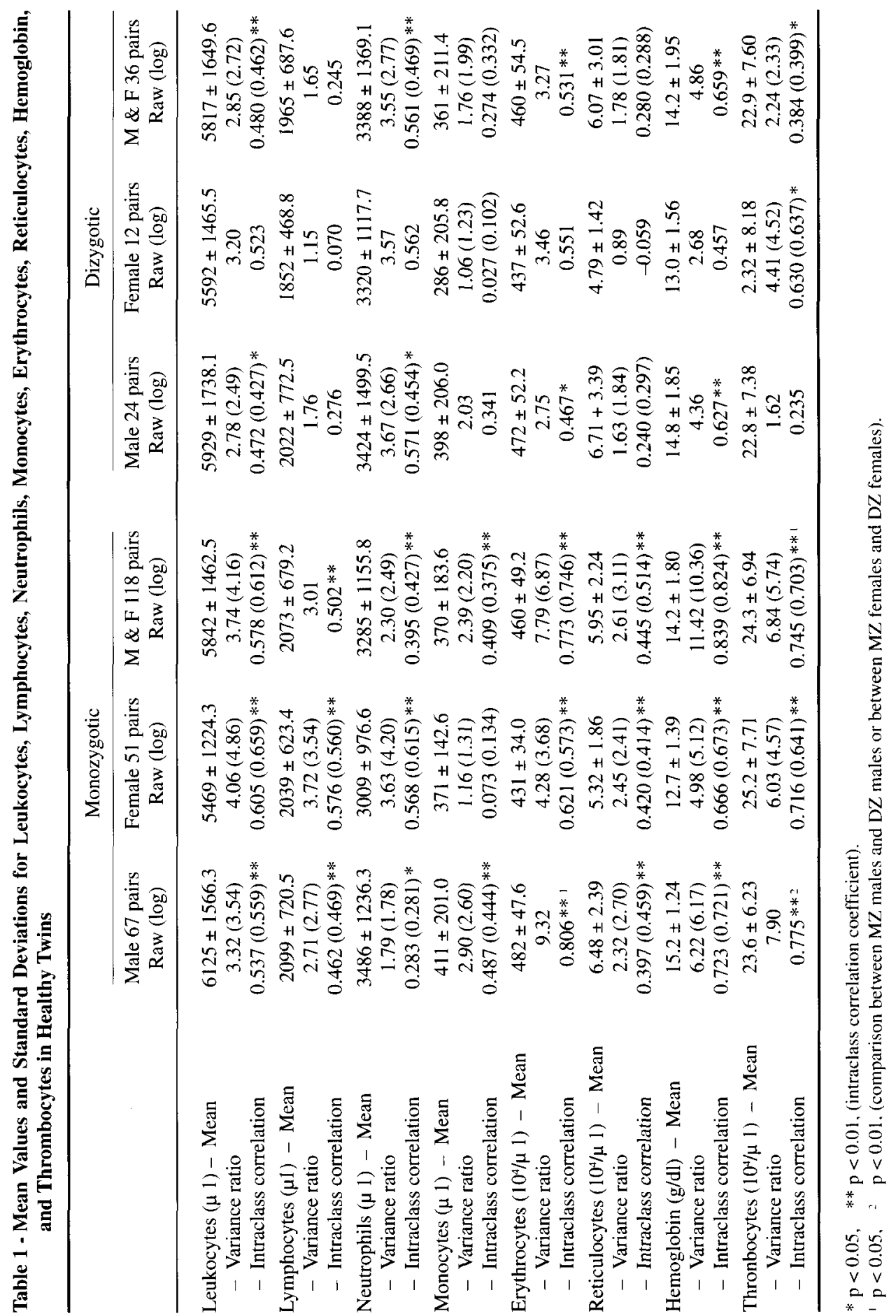




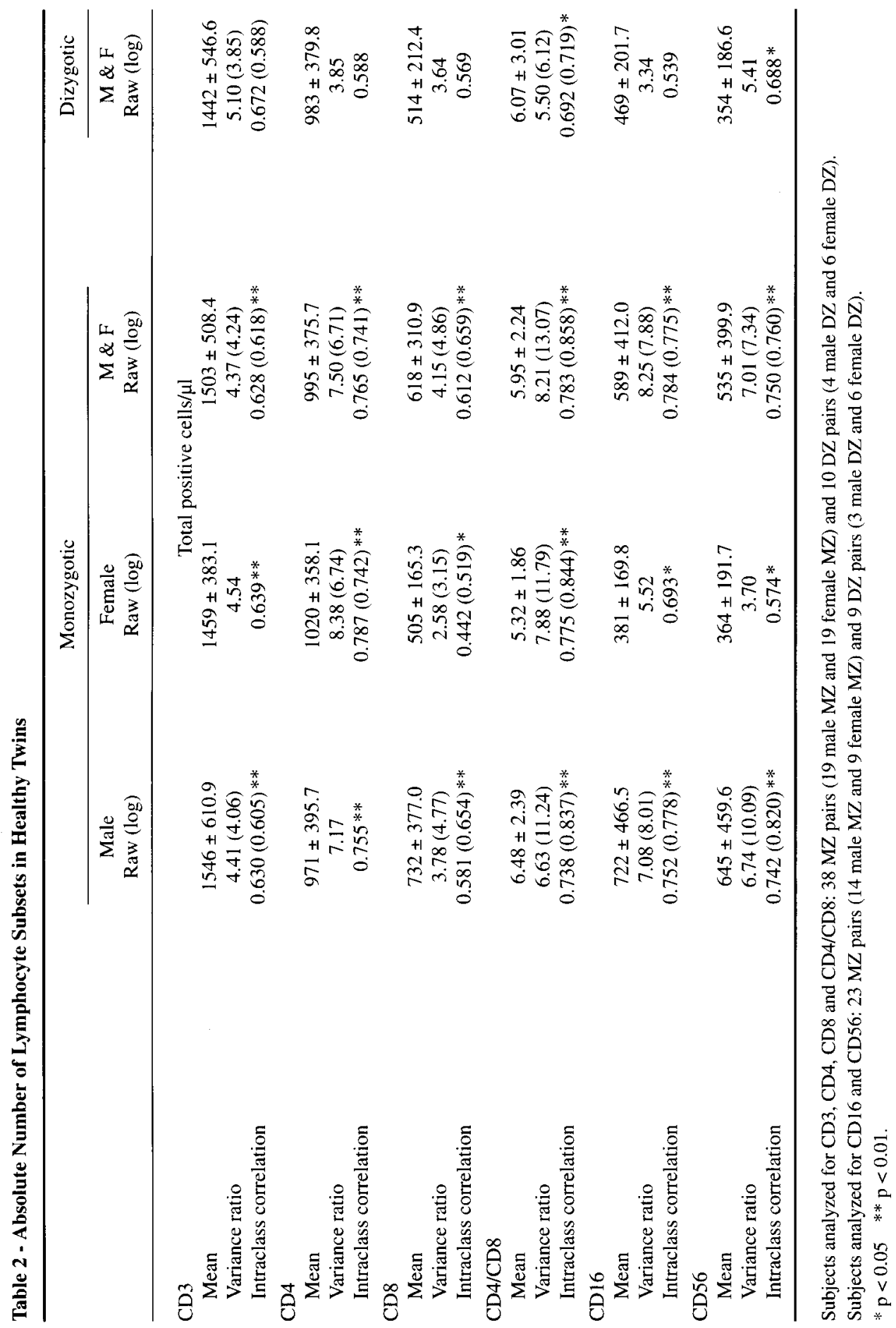


Table 3 - Influence of Age on Leukocytes, Lymphoytes, Neutrophils, Monocytes, Erythrocytes, Reticulocytes, Hemoglobin and Thrombocytes in MZ twins

\begin{tabular}{|c|c|c|c|}
\hline & \multicolumn{3}{|c|}{ Monozygotic twins } \\
\hline & $\begin{array}{c}\leq 39 \\
\text { Raw (log) } \\
(\mathrm{n}=19)\end{array}$ & $\begin{array}{c}40-59 \\
\text { Raw (log) } \\
(n=65)\end{array}$ & $\begin{array}{c}60 \leq \\
\text { Raw (log) } \\
(\mathrm{n}=34)\end{array}$ \\
\hline \multicolumn{4}{|l|}{ Leukocytes $(\mu 1)$} \\
\hline Mean & $5561 \pm 1524.8$ & $6088 \pm 1317.9$ & $5528 \pm 1616.1$ \\
\hline Variance ratio & $2.29(2.85)$ & 3.48 & $5.20(5.54)$ \\
\hline Intraclass correlation & $0.393(0.481)^{*}$ & $0.553 * *$ & $0.677(0.694)^{* *}$ \\
\hline \multicolumn{4}{|l|}{ Lymphoytes $(\mu 1)$} \\
\hline Mean & $1982 \pm 704.5$ & $2155 \pm 675.4$ & $1964 \pm 659.8$ \\
\hline Variance ratio & $3.79(4.09)$ & $2.76(2.59)$ & 3.06 \\
\hline Intraclass correlation & $0.583(0.607)^{* *}$ & $0.468(0.443)^{* *}$ & $0.507 * *$ \\
\hline \multicolumn{4}{|l|}{ Neutrophils $(\mu 1)$} \\
\hline Mean & $3089 \pm 1125.0$ & $3412 \pm 1074.0$ & $3155 \pm 1311.0$ \\
\hline Variance ratio & $2.65(2.49)$ & $2.02(2.15)$ & $2.58(2.98)$ \\
\hline Intraclass correlation & $0.452(0.426)$ & $0.339(0.365)^{* *}$ & $0.441(0.498)^{* * *}$ \\
\hline \multicolumn{4}{|l|}{ Monocytes $(\mu 1)$} \\
\hline Mean & $299 \pm 126.9$ & $377 \pm 193.5$ & $400 \pm 183.2$ \\
\hline Variance ratio & 1.82 & $2.71(1.98)$ & $1.77(1.82)$ \\
\hline Intraclass correlation & 0.292 & $0.460(0.330)^{* *}$ & $0.279(0.290)$ \\
\hline \multicolumn{4}{|l|}{ Erythrocytes $\left(10^{4} / \mu 1\right)$} \\
\hline Mean & $477 \pm 58.3$ & $459 \pm 46.0$ & $451 \pm 47.7$ \\
\hline Variance ratio & 27.24 & $5.03(3.66)$ & 9.84 \\
\hline Intraclass correlation & $0.929 * *$ & $0.668(0.571)^{* * 2}$ & $0.815^{* *}$ \\
\hline \multicolumn{4}{|l|}{ Reticulocytes $\left(10^{4} / \mu 1\right)$} \\
\hline Mean & $4.62 \pm 1.41$ & $6.03 \pm 2.23$ & $6.57 \pm 2.33$ \\
\hline Variance ratio & 14.63 & $1.99(1.98)$ & 2.16 \\
\hline Intraclass correlation & $0.872 * *$ & $0.330(0.330)^{* * 2}$ & $0.367^{* 2}$ \\
\hline \multicolumn{4}{|l|}{ Hemoglobin $(\mathrm{g} / \mathrm{dl})$} \\
\hline Mean & $14.1 \pm 2.49$ & $14.2 \pm 1.75$ & $14.2 \pm 1.42$ \\
\hline Variance ratio & 15.63 & $10.83(9.00)$ & 9.40 \\
\hline Intraclass correlation & $0.880 * *$ & $0.831(0.800)^{* *}$ & $0.808 * *$ \\
\hline \multicolumn{4}{|l|}{ Thrombocytes $(104 / \mu 1)$} \\
\hline Mean & $24.7 \pm 8.52$ & $25.0 \pm 7.30$ & $22.8 \pm 4.86$ \\
\hline Variance ratio & $7.02(3.47)$ & $7.19(6.09)$ & 5.31 \\
\hline Intraclass correlation & $0.751(0.553) *$ & $0.756(0.718)^{* *}$ & $0.683 * *$ \\
\hline
\end{tabular}

$* \mathrm{p}<0.05, \quad * * \mathrm{p}<0.01$, (intraclass correlation coefficient).

${ }^{1} \mathrm{p}<0.05,{ }^{2} \mathrm{p}<0.01$, (comparison between $\leq 39$ years of age and other age groups). 
Table 4 shows the mean absolute numbers and intraclass correlations for $\mathrm{CD}^{+}$, $\mathrm{CD}^{+}, \mathrm{CD}^{+}, \mathrm{CD}^{+} 6^{+}$, and $\mathrm{CD} 56^{+}$cells according to age. The subjects were classified into two age groups ( $\geq 60$ years, $<60$ years) since the number of subjects for the analysis of these subsets was small. The intraclass correlation for $\mathrm{CD}^{+}$cells was lower in the pairs aged $\geq 60$ years than in those aged $<60$ years. $\mathrm{CD}^{+}$cells and the $\mathrm{CD}^{+} / \mathrm{CD}^{+}$cell ratio showed high intraclass correlations regardless of age.

Table 4 - Influence of Age on Absolute Numbers of Lymphocyte Subsets ( $\mathrm{CD3}^{+}, \mathrm{CD4}^{+}, \mathrm{CDB}^{+}$, $\mathrm{CD}^{+} 6^{+} \mathrm{CD56}^{+}$cells and CD4/CD8) in MZ Twins

\begin{tabular}{|c|c|c|}
\hline & $\begin{array}{c}\leq 59 \\
\text { Raw }(\log )\end{array}$ & $\begin{array}{c}60 \leq \\
\text { Raw }(\log )\end{array}$ \\
\hline & \multicolumn{2}{|c|}{ Total positive cells $/ \mu 1$} \\
\hline \multicolumn{3}{|l|}{ CD3 } \\
\hline Mean & $1541 \pm 529.9$ & $1419 \pm 457.7$ \\
\hline Variance ratio & $6.14(5.17)$ & 2.17 \\
\hline Intraclass correlation & $0.720(0.676)^{* *}$ & 0.368 \\
\hline \multicolumn{3}{|l|}{$\mathrm{CD} 4$} \\
\hline Mean & $1010 \pm 374.5$ & $965 \pm 384.4$ \\
\hline Variance ratio & 8.13 & 6.91 \\
\hline Intraclass correlation & $0.781 * *$ & $0.747 * *$ \\
\hline \multicolumn{3}{|l|}{ CD8 } \\
\hline Mean & $591 \pm 261.5$ & $677 \pm 397.8$ \\
\hline Variance ratio & $6.36(5.46)$ & $3.10(4.38)$ \\
\hline Intraclass correlation & $0.728(0.690)^{* *}$ & $0.512(0.628)^{*}$ \\
\hline \multicolumn{3}{|l|}{$\mathrm{CD} 4 / \mathrm{CD} 8$} \\
\hline Mean & $1.90 \pm 0.92$ & $1.87 \pm 1.31$ \\
\hline Variance ratio & $10.55(16.78)$ & $7.02(11.17)$ \\
\hline Intraclass correlation & $0.827(0.887)^{* *}$ & $0.751(0.836)^{* *}$ \\
\hline \multicolumn{3}{|l|}{ CD16 } \\
\hline Mean & $527 \pm 292.0$ & $730 \pm 594.3$ \\
\hline Variance ratio & $8.12(7.01)$ & $8.54(9.87)$ \\
\hline Intraclass correlation & $0.781(0.750)^{* *}$ & $0.790(0.816)^{*}$ \\
\hline \multicolumn{3}{|l|}{ CD56 } \\
\hline Mean & $452 \pm 240.8$ & $726 \pm 599.1$ \\
\hline Variance ratio & $5.74(5.96)$ & $7.18(11.95)$ \\
\hline Intraclass correlation & $0.703(0.713)^{* *}$ & $0.756(0.846)^{*}$ \\
\hline
\end{tabular}

Subjects analyzed for CD3, CD4, CD8 and CD4/CD8: $38 \mathrm{MZ}$ pairs (26 MZ pairs aged $\leq 59$ years and $12 \mathrm{MZ}$ pairs aged $60 \leq$ years).

Subjects analyzed for CD 16 and CD56: $23 \mathrm{MZ}$ pairs ( $16 \mathrm{MZ}$ pairs aged $\leq 59$ years and $7 \mathrm{MZ}$ pairs aged $60 \leq$ years).

$* \mathrm{p}<0.05 \quad * * \mathrm{p}<0.01$. 


\section{Influence of Lifestyle}

Table 5 compares the mean values of leukocytes, lymphocytes, neutrophils, monocytes, erythrocytes, reticulocytes, hemoglobin, and platelets between MZ twins who showed intrapair differences in alcohol consumption, cigarette consumption, occupation, or body weight.

Of the $118 \mathrm{MZ}$ pairs, 16 pair showed relatively marked intrapair differences in alcohol consumption, fulfilling the following criteria.

1. The mean daily alcohol consumption in one member of the pair was more than twice compared to that in the other.

2. The intrapair difference in alcohol consumption was at least $40 \mathrm{ml} /$ day as pure ethyl alcohol.

3. The mean daily alcohol consumption was less than $100 \mathrm{ml}$ of ethanol, and there were no symptoms of alcoholism.

The ethanol consumption was about $57 \mathrm{ml} /$ day in the higher consumer group and about $10 \mathrm{ml} /$ day in the lower consumer group. However, no significant difference was observed in any variable between the two groups.

Of the $118 \mathrm{MZ}$ pairs, 15 pairs showed intrapair differences in cigarette consumption according to the following criteria.

1. One member of the pair smoked 20 cigarettes/day or more, and the other smoked no cigarette or smoked 5 cigarettes/day or less.

2. The intrapair difference in cigarette consumption was 20 cigarettes/day or more.

The higher consumer group smoked about 25 cigarettes/day, and the lower consumer group smoked almost no cigarettes. However, no significant difference was observed in any variable between the two groups.

It is common for Japanese to be engaged in a single occupation throughout their lives. The subjects were classified according to the occupation classification in the vital statistics according to occupations by the Japanese Ministry of Health and Social Welfare [11] into 11 groups (A, professional and technical workers; B, managers and officials; C, clerical and related workers; D, sales workers; E, agricultural, forestry and fisheries workers; F, mining workers; $\mathrm{G}$, workers in transport and communications occupations; $\mathrm{H}$, craftsmen, production process workers; I, protective service workers; J, service workers; $\mathrm{K}$, workers not classifiable by occupation). In this study, A, B, and $\mathrm{C}$ were considered to be the 'light work' group, and E, F, and H to be the 'heavy work' group. In 17 of the $118 \mathrm{MZ}$ pairs, one member was classified as the 'heavy work' group, and the other as the 'light work' group.

However, no significant difference was observed in any variable between the two groups.

Of the $118 \mathrm{MZ}$ pairs, 32 pairs showed intrapair differences in body weight according to the following criteria.

1. The intrapair difference in body weight was $\geq 6 \mathrm{~kg}$.

2. The intrapair difference in height was $\leq 2 \mathrm{~cm}$. 


\section{Intrapair Differences of the Blood Cell Components 211}

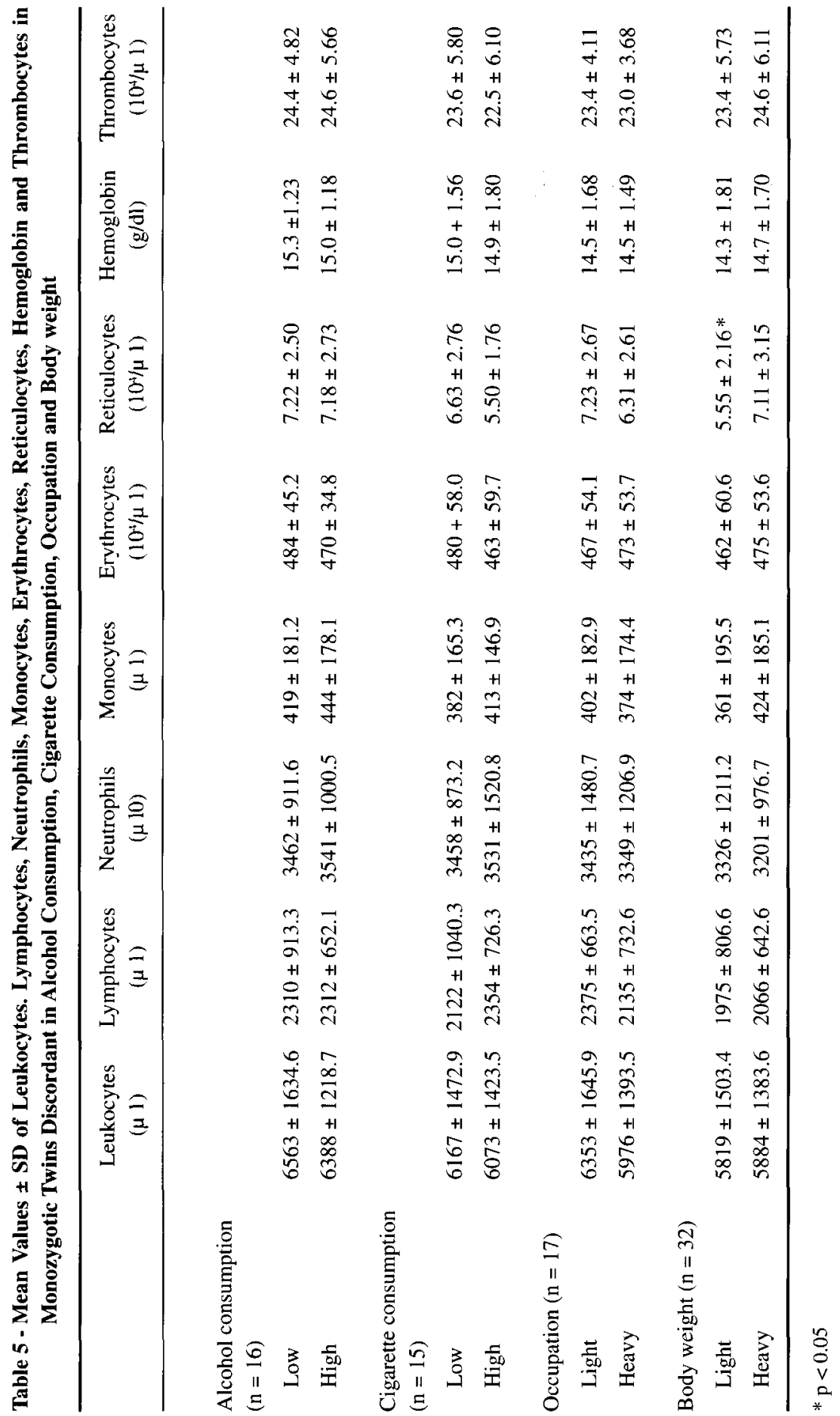




\section{Y. Yokoyama et al.}

The body weight in the heavier group was $65.8 \mathrm{~kg}( \pm 12.1 \mathrm{~kg})$, and that in the lighter group was $55.1 \mathrm{~kg}( \pm 9.4 \mathrm{~kg})$. The mean intrapair difference in height was $0.2 \mathrm{~cm}$. The reticulocyte count was significantly lower in the lighter group than in the heavier group $(\mathrm{p}<0.05)$.

The association between the environmental factors and lymphocyte subsets could not be evaluated because of the small number of subjects examined. However, in $3 \mathrm{MZ}$ pairs showing occupational differences, the absolute numbers of $\mathrm{CD} 16^{+}$and $\mathrm{CD} 56^{+}$cells were higher in twins in the 'heavy work' group than in those in the 'light work' group. The absolute numbers of $\mathrm{CD}^{2} 6^{+}$cells in the 'heavy work' twin and 'light work' twin in the 3 pairs were 1024 and $724(\mu 1), 633$ and 529, and 278 and 195, respectively. The absolute numbers of CD56+ cells in the 'heavy work' twin and 'light work' twin in the 3 pairs were 1546 and $876(\mu 1), 442$ and 416 , and 266 and 100, respectively.

\section{DISCUSSION}

The degree of genetic control of cells that differentiate from hematopoietic cells and the influence of environmental factors on these cells are still unclear. Studies on twins are useful to evaluate the influence of genetic and environmental factors.

Since number of DZ twins was low in this study, further studies are needed on the genetic contribution rate in additional cases. In this study, the intraclass correlation was primarily analyzed in $\mathrm{MZ}$ and $\mathrm{DZ}$ twins. The influence of environmental factors varied even among cells that differentiated from the same hematopoietic cells. Platelets and erythrocytes showed significantly high intraclass correlations in the male MZ pairs, suggesting marked genetic control. Anti-platelet antibodies such as CD9, CD41, CD42a, and CD42b were not evaluated in this study. These antibodies may also show high genetic contribution rates in the males. On the other hand, in the females, no difference was observed in the intraclass correlation for platelets or erythrocytes between the $\mathrm{MZ}$ and DZ pairs. This might be associated with menstruation in females.

On the other hand, the intraclass correlations for neutrophils and monocytes were relatively low. This finding suggests that the degree of changes in these cells is affected by environmental factors rather than genetic factors. Neither neutrophils or monocytes were associated with alcohol consumption, cigarette consumption, occupation, or body weight. Lymphocytes showed a moderate intraclass correlation in the MZ twins, suggesting that the degree of influence by genetic factors is similar to that by environmental factors.

T lymphocytes are roughly classified into $\mathrm{CD} 4^{+}$cells and $\mathrm{CD} 8^{+}$cells. The former bind to class II MHC molecules, the latter to class I MHC and regulate immunoresponses as helper / inducer $\mathrm{T}$ cells and suppressor / cytotoxic $\mathrm{T}$ cells, respectively. NK cells injure, in a non-restraint manner, autologous, isologous, homologous, and heterologous tumor cells, and their membrane surface markers are CD3, CD4, CD8, TCR, CD16+, and $\mathrm{CD}^{2} 6^{+}$.

In this study, the intraclass correlations for the absolute numbers of $\mathrm{CD3}^{+}, \mathrm{CD}^{+}$, and $\mathrm{CD}^{+}$cells and the $\mathrm{CD}^{+} / \mathrm{CD} 8^{+}$cell ratio were higher in the $\mathrm{MZ}$ pairs than in the $\mathrm{DZ}$ pairs. In particular, the intraclass correlation for $\mathrm{CD}^{+}$cells was high in both male and female MZ pairs and was constant irrespective of age. These results indicate the marked 
genetic influence on the absolute number of $\mathrm{CD}^{+}$cells and also support the report that $\mathrm{CD}^{+}$cells expressing $\mathrm{V} \beta$ gene of TCR in MZ pairs are strictly limited. The intraclass correlation for the absolute number of $\mathrm{CD}^{+}$cells was slightly lower than that for $\mathrm{CD}^{+}$ cells. However, the $\mathrm{CD} 4^{+} / \mathrm{CD} 8^{+}$cell ratio showed an even higher intraclass correlation both in the males and females regardless of age. This also indicates marked genetic regulation of $\mathrm{CD}^{+} / \mathrm{CD}^{+}$cell ratio in healthy twins. On the other hand, the absolute number of $\mathrm{CD}^{+}$cells showed a considerably low intraclass correlation in the pairs aged $\geq 60$ years.

In general, the absolute number of cells decreases with age. It has been observed a decrease in the absolute numbers of $\mathrm{CD}^{+}$cells and $\mathrm{CD} 8^{+}$cells with age [7]. The absolute number of $\mathrm{CD}^{+}$cells was slightly decreased in the twins aged $\geq 60$ years in this study. Since the number of subjects was small in the present study, further studies are needed in additional cases on the association between the $\mathrm{CD} 3^{+}$cells and aging.

The number of cells in NK cell subsets has been reported to be increased in aged subjects $[1,2,15]$. Our results are consistent with this finding. On the other hand, the absolute numbers of $\mathrm{CD} 16^{+}$cells and $\mathrm{CD}^{2} 6^{+}$cells showed high intraclass correlations in the $\mathrm{MZ}$ pairs and further higher correlations in the pairs aged $\geq 60$ years than in those aged $<60$ years. NK cells are derived from hematopoietic stem cells. However, their differentiation process remains unclear. The high intraclass correlation even in aged twins suggests only slight effects of age on NK cells and the differentiation of these cells under marked genetic control. The association between NK cells and environmental factors could not be evaluated because of the small number of subjects. However, in MZ pairs, the absolute number of NK cells was slightly higher in twins who were engaged in heavy work than in twins engaged in light work. This finding requires further investigation.

The intraclass correlations for the values of $T$ lymphocyte subsets and NK cell subsets were lower in the $\mathrm{DZ}$ pairs than the $\mathrm{MZ}$ pairs but were relatively high even in the DZ pairs (0.5-0.7). In this study, healthy pairs were selected as subjects. Therefore, it is possible that there was selection bias in terms of genetic characters among siblings and environmental conditions. This should be taken into consideration when the results of this study are interpreted.

Acknowledgements: We express our deep gratitude to Prof. Tadahiko Shimizu at our department for instructions from the beginning of our study, and to Prof. Kazuo Hayakawa at Osaka University and Prof. Yasushi Ohba at the Department of Clinical Pathology of our university for cordial instructions. We also thank the staff at our department for cooperation in examination, the staff at the Central Laboratory of our university for cooperation in the measurement of lymphocyte subsets, and the twins who voluntarly underwent examination.

\section{REFERENCES}

1. Abo T, Cooper MD, Balch CM (1982): Postnatal expansion of the natural killer and killer cell population in humans identified by the monoclonal HNK-1 antibody. J Exp Immunol 155: 321-326. 


\section{Y. Yokoyama et al.}

2. Abo T, Miller C, Balch C (1984): Characterization of human granular lymphocyte subpopulations expressing HNK-1 (Leu-7) and Leu-11 antigens in the blood and lymphoid tissues form fetuses, neonates and adults. Eur J Immunol 14: 616-623.

3. Awanaka T, Ishikawa E (1979): Shin Tokei Gaku. Tokyo: Maki Books.

4. Davey MP, Meyer MM., Bakke A C (1994): T cell receptor VB gene expression in monozygotic twins, discordance in CD8 subset and in disease states. Journal of Immunology 152: 315-321.

5. Dunlap NE, Ballinger S, Reed T, Christian JC, Koopman WJ, Briles DE (1993): The use of monozygotic and dizygotic twins to estimate the effects of inheritance on the levels of immunoglobulin isotypes and antibodies to phosphocholine. Clinical Immunology and Immunopathology 66: 176-180.

6. Ericsson CH, Svartengren M, Mossberg B, Camner P (1993): Bronchial reactivity, lung function, and serum immunoglobulin $\mathrm{E}$ in smokingdiscordant monozygotic twins. Am Rev Respir Dis 147: 296-300.

7. Goto M, Nishioka K (1989): Age- and sex-related changes of the lymphocyte subsets in healthy individuals: an analysis by two-dimensional flow cytometry. Journal of Gerontology 44: M51-56.

8. Hanson B, McGue M, Roitman-Johnson B, Segal NL, Bouchard TJ, Blumental MN (1991): Atopic disease and immunoglobulin $\mathrm{E}$ in twins reared apart and together. Am $\mathrm{J}$ Hum Genet 48: 873-879.

9. Hayakawa K, Shimizu T, Ohba Y, Tomioka S (1987): Lifestyle factors affecting intrapair differences of serum apoproteins and cholesterol concentrations in adult identical twins. Atherosclerosis 66: 1-9.

10. Hayakawa K, Shimizu T (1987): Blood pressure discordance and lifestyle; Japanese identical twins reared apart and together. Acta Genet Med Gemellol 36: 485-491.

11. Japan Ministry of Health and Social Welfare (1984): Population Survey by Occupation and Industry in 1984. Tokyo: Japan Ministry of Health and Social Welfare.

12. Matour D, Melnicoff M, Kaye D, Murasko DM (1989): The role of T cell phenotypes in decreased lymphoproliferation of the elderly. Clinical immunology and immunopathology 50: $82-99$.

13. Paoli PD, Battistin S, Santini GF (1988): Age-related changes in human lymphocyte subsets: progressive reduction of the CD4 CD45R (suppressor inducer) population. Clinical immunology and immunopathology 48: 290-296.

14. Peakman M, Alviggi L, Hussain MJ, Lo SSS, Hawa M, Leslie RDG, Vergani D (1994): Increased expression of T-cell markers of immunological memory associated with protection from type I diabetes. Diabetes 43: 712-717.

15. Reichert T, DeBruyere M, Deneys V, Totterman T, Lydyard P, Yuksel F, Chapel H, Jewell D, Hove LV, Linden J, Buchner L (1991): Lymphocyte subset reference ranges in adult caucasians. Clinical Immunology and Immunopathology 60: 190-208.

16. Snedecor GW, Cochran WG (1984): Statistical Methods 6th Edn. Translated by Hatamura Y, et al., Tokyo: Iwanamishoten.

17. Yokoyama Y, Shimizu T, Hayakawa K (1995): Prevalence of cerebral palsy in twins, triplets, and Quadruplets. International Journal of Epidemiology 24: 943-948.

18. Yokoyama Y, Shimizu T, Hayakawa K (1995): Incidence of handicaps in multiple births and associated factors. Acta Genet Med Gemellol (in press).

19. Yokoyama Y, Shimizu T, Hayakawa K (1995): Handicaps in twins and triplets. Jpn J Hyg 49: 1013-1018.

Correspondence: Yoshie Yoykoyama, Department of Public Health, Kinki University School of Medicine, 377, Ohnohigashi Osakasayama city, Osaka, 589, Japan. 